\title{
Text Attributed with Language Attitude in Indonesian Language Instruction as The Efforts to Knit Nationalism in a Frame of Diversity
}

\author{
I Putu Mas Dewantara \\ Universitas Pendidikan Ganesha \\ Jl. Udayana No. 11, Singaraja, Bali. 81116, Indonesia
}

\begin{abstract}
This research aims to 1) describe the use of text attributed with language attitude in Indonesian language instruction and 2) describe student's response to the instruction. It was a descriptive research which data were collected by using observation method and questionnaire. The subjects were 4 lecturers of Indonesian language and 258 students of Unversitas Pendidikan Ganesha. The results of this study indicate that 1) text attributed with language attitude was applied in 4 main steps, namely (1) preparation of conditions, (2) reading of text in groups, (3) intergroup discussions, (4) inferences; 2) Student response in terms of interest, $55.91 \%$ of students were very interested, $38.76 \%$ of students were interested, and $5.33 \%$ were less interested. In terms of textual ability to inspire the sense of nationalism, $63.70 \%$ of students felt the text was very capable to do it, $32.43 \%$ of students felt the text was capable enough to do it, and $3.88 \%$ of students felt the text was less inspiring to raise nationalism within the frame of diversity. Thus, learning was able to attract students and the text used was able to awaken nationalism within the frame of diversity. The implication is the existence of teaching materials to nurture nationalism.
\end{abstract}

Keyword: text, language attitude, Indonesian language, nationalism, diversity

\section{Introduction}

Recently, the discussions of nationalism in the framework of diversity are widely practiced. This can not be separated from various problems related to the spirit of nationalism that occurred. There has been a degradation of the spirit of unity $[1,2]$. Therefore, it is necessary to build multicultural awareness to foster the spirit of nationalism in a diversity frame. Multiculturalism is a spirit that appreciates diversity, whether cultural diversity, ethnicity, religion, or other forms of diversity [3,4,1,5]. Multicultural awareness is the instrument of national therapy [6]. In addition, an understanding of nationalism, identity politics, and a sense of solidarity also needs to be enhanced to foster a spirit of nationality in order to overcome this nation's growing problems $[7,8]$. Diversity should 
have been viewed as a destiny of God's grace from a long process of the nation's journey that must be cherished [9].

Permendikbud No.21 of 2015 on Character Building Movement at School is a form of understanding of the awareness of national identity and nationalism. In addition, the slogan "Aku Indonesia, Aku Pancasila" is also a sign of the necessity of strategic efforts in fostering the spirit of nationalism within the framework of diversity in the present. One of various strategic efforts such as by applying the project model of citizens in the learning of Citizenship [10]. The result of the implementation of this model is able to develop students' nationalism attitude. The study of the movie "Land of Heaven Said" as a media for the growth of students' nationalism attitude has also been done [11]. The results of this study indicate the influence of film media as a medium for growing nationalism attitudes. It seems that fostering the nationalism spirit needs to be done through the review of nationalism history itself $[12,8]$.

The growth of nationalism spirit is also done in learning Indonesian and Literature. The study of the novel and its implications for Indonesian Language and Literature learning has been done in an effort to foster nationalism $[13,14]$. Another step taken is the development of anti-corruption education materials integrated with Indonesian language learning which one of its goals is to foster nationalism [15]. Until now there has been no research on learning Indonesian in Higher Education in an effort to grow nationalism. Therefore, this research tries to offer an attempt to overcome the problem of nationalism in the framework of diversity. The effort is through a text charged with language attitudes. The content of language attitudes can be used as a means to love the Indonesian language in particular and the Indonesian nation in general. Indonesian is the foundation of the nation [16]. This is the adhesive language of the nation.

\section{Method}

This research is descriptive research. The data of this research were 1) the steps of using the text of the attitude of the language in Indonesian language learning and 2) the student's response toward the learning. The subjects were 4 lecturers of Indonesian language subjects and 258 students of Universitas Pendidikan Ganesha. There were two methods of data retrieval used in this research, those were observation and questionnaire. The observation was done to know the steps of learning applied by the lecturer and the questionnaire was done to know the student's response toward the learning process. Data analysis was done through three stages, namely data reduction, data presentation, and inference and verification.

\section{Results and Discussion}

\subsection{The steps of Indonesian Language Learning by using the Text of Language Attitudes were applied in 4 steps}

1) Preparation

This step aimed to stimulate interest and motivation of students in learning. At this stage the lecturer explains the various problems facing by this nation related to nationalism in the frame of diversity. This stage is an important step considering that motivation is the overall driving force in the learners that leads to learning activities, ensures learning activities, and gives direction for learning objectives can be achieved [17,18]. The results showed that motivation factor contributed $67 \%$ to reading culture [19]. Therefore, it is important to generate students' motivation before learning Indonesian by using 
phenomenon text of language attitudes. Besides storytelling, the other activities that was done by the lecturer in this step was showing the picture or video related to nationalism problem. The use of historical stories and problems in everyday life was aimed to make the problems more easily understood by the students.

\section{2) Reading text in groups}

When the students were motivated to learn, the next stage was grouping. The groups were heterogeneous group consists of 3-5 students. The heterogeneous group formations are very appropriate for the college level and can improve learning outcomes [20,21,22]. The next stage was distributing the phenomenon text with language attitude. The students were assigned to read the texts and discuss it in groups and trace information related to the reading material. What students do at this stage was to find the source and choose the best source. A variety of sources of information can be used in the form of photographs, drawings, texts, diagrams, videos, etc. so it is necessary to sort out related sources that can be used to better understand the text of phenomena distributed by professors [23]. The investigation of the information wasa divided into 5 stages, namely (1) determining the information needs, (2) accessing the information needed effectively and efficiently; (3) providing critical evaluation and sorting information; (4) understanding the information; and (5) using it ethically And legaly [24]. The result of the research showed that the steps had been done by the students with the instruction of the lecturer.

\section{3) Intergroup discussion}

At this stage, the students did intergroup discussion by conveying their understanding of the text that had been read and enriched by other information. Other groups should listen and give comment on the other groups' understanding. This intergroup discussion aims to re-evaluate the understanding like what had been done by other groups at the previous step.

\section{4) Conclusion}

This step is a step that was done together by students and lecturers. The steps were done by the lecturers, where the lecturers gave students the opportunity to make conclusions regarding to the texts that have been distributed. The lecturers seen to help the students to conclude the text in accordance with the results of the discussions that had been done.

\subsection{Student Response}

The student's response toward Indonesian Language Learning by using the Text of Language Attitudes could be seen from the students' interest. It can be seen in Figure 1.

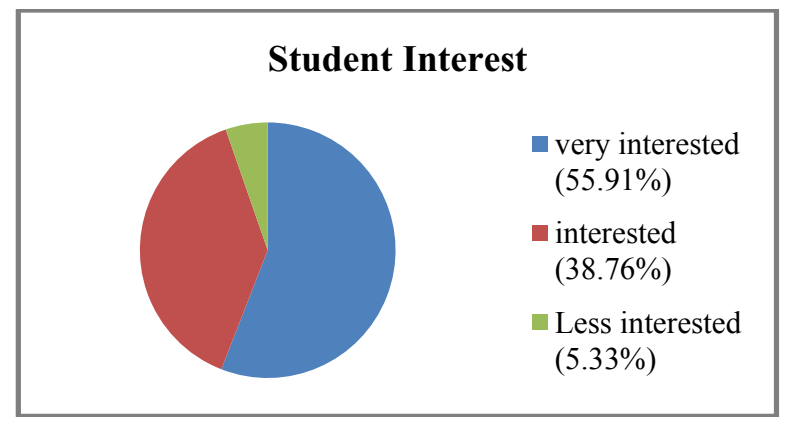

Fig. 1 Student Interest Response in Following Learning 
Figure 1. shows that students are interested in learning Indonesian by using text of language attitudes. Four questions are used to determine the interest of students in following the learning process, such as (1) the attractiveness of learning, (2) the feelings of learning, (3) motivation, and (4) the desire to learn by using text of language attitudes. During this Indonesian language learning has been running well, but cannot attract the students' interest due to the limited resources or learning media used by the lecturers [25,26]. The att ondance of language-laden text is expected to overcome the weaknesses of previous Indonesian language learning.

The ability of the Text of Language Attitudes in arousing the spirit of nationalism in the frame of diversity can be seen in Figure 2.

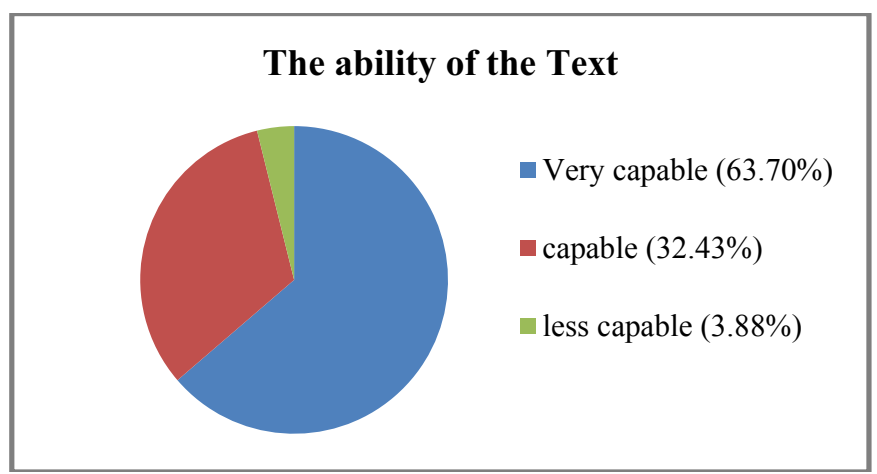

Fig. 2 Text Ability Awakens the Spirit of Nationalism

Figure 2 shows that the text of the attitudes of language is capable in arousing the spirit of nationalism in a diversity frame. The six indicators used to measure nationalism are (1) the position and role of the Indonesian language, (2) awareness of threats and challenges, (3) awareness of diversity, (4) awareness of the role of self in maintaining nationalism, (5) the love of the motherland, and (6) positive attitude toward language and nation. The results of this study were emphasizing on the premise that education, language, and culture are important factors in fostering nationalism [27]. In addition, the results of this study also reinforce opinions that emphasize the relationship of nationalism and language learning by saying that the formation of nationalist attitudes can be done through language learning [28]. This is also done by Malaysia through 'Enforcing Bahasa Malaysia and Strengthening English [29] as well as by the Taiwanese community through the curriculum of Mother Language Education [30]. Therefore, language learning is packed using text of language attitudes with the goal of developing positive language attitudes that can arousing nationalism within a diversity frame. A strong and prominent national identity can overcome ethnic barriers to believe in diverse communities [31].

\section{Conclusion}

Indonesian Language Learning by using the Text of Language Attitudes is conducted through four main stages: preparing conditions, reading in groups, intergroup discussions, and inferences. Students interested and feel that the text of language attitudes used in learning process can foster the spirit of nationalism. The implication of this research is that the text can be used as a medium of growing nationalism to unite nationalism in the frame of diversity. 


\section{References}

1. A. M. A. Shofa, J. Pancasila dan Kewarganegaraan, 1(1), 34-41 (2016)

2. L. Agung, Int. J. Hist. Educ., 12(2), 392-403 (2011)

3. D. A. Tanudirjo, Membangun Pemahaman Multikulturalisme: Perspektif Arkeologi (Solo, 2011).

4. G. Lestari, J. Pendidik. Pancasila dan Kewarganegaraan, 28(1), 31-37 (2015)

5. R. B. Pratama and S. D. Kharisma, "Insight oriented multicultural education nationality for resilience in moral era mea," in Proceedings International Seminar FoE (Faculty of Education), 2016, pp. 71-83.

6. A. Abdullah and Hannati, "Nasionalisme Dipertanyakan Kembali (Renungan Perjalanan Sejarah Bangsa 71 Tahun Indonesia Merdeka)," in Pendidikan Ilmu-Ilmu Sosial Membentuk Karakter Bangsa Dalam Rangka Daya Saing Global, 2016, pp. 377-390.

7. M. Z. Alfaqi, J. Pancasila dan Kewarganegaraan, 28(2), 111-116 (2015)

8. R. Wodak and S. Boukala, J. Lang. Polit., 14(1), 87-109 (2015)

9. G. Kasnowihardjo, J. Berk. Arkeol., 36(2), 161-172 (2016)

10. H. Maksum, PIONIR J. Pendidik., 3(1), 1-11 (2015)

11. R. R. Wijaya, E-CIVICS, 5(2), 1-13 (2016)

12. M. Z. Alfaqi, J. Civ., 13(2), 209-216 (2016)

13. A. Hirata, "Nasionalisme Dalam Novel Sebelas Patriot Karya Andrea Hirata dan Implikasinya Terhadap Pembelajaran Bahasa dan Sastra Indonesia di Sekolah,” 2016.

14. S. Kirom, "Novel Tak Ada Lain Karya Suparto Brata (Kajian Psikologi Sastra, Nilai Karakter, dan Relevansinya dengan Pembelajaran Bahasa Indonesia di SMA)," 2015.

15. M. W. Nugraheni, "Pendidikan Antikorupsi dalam Model Pembelajaran Bahasa Indonesia Terintegrasi Siswa Kelas VII Semester I SMP Negeri 1 Tembarak Tahun Ajaran 2010/2011," vol. 12, no. 1, pp. 14-27, 2016.

16. Mahsun, "Merajut Kebinekaan Bahasa sebagai Pemerkukuh Ikatan Kebangsaan." [Online]. Available: http://fkip.untidar.ac.id/wp-content/uploads/2016/10/Mahsunmerajut-kebinekaan-bahasa-sebagai-pemerkukuh-ikatan-kebangsaan.pdf. .

17. M. U. Usman, Menjadi Guru Profesional. (Bandung: Remaja Rosdakarya, 2002)

18. P. Buckley and E. Doyle, Interact. Learn. Enviroments, 24(6), 1162-1175 (2016)

19. Pranowo and A. Herujiyanto, Masy. Linguist. Indones., 33(2), 153-171 (2015)

20. V. D. Tran, A. Giang, and A. Giang, "The Effects of Cooperative Learning on the Academic Achievement and Knowledge Retention," vol. 3, no. 2, pp. 131-140, 2014.

21. R. M. Gillies and R. M. Gillies, Int. J. Educ. Psychol., vol. 3, no. 2, pp. 125-140, 2014.

22. A. Macpherson, Cooperative Learning Group Activities for College Courses. Surrey, BC( Canada: Kwantlen Polytechnic University, 2015)

23. A. Nurohman, J. Kependidikan, 2(1), 1-25, (2014) 
24. B. Johnston, S. Webber, and B. Johnston, Stud. High. Educ., 28(3), 335-352 (2003)

25. I. K. Dibia, I. P. M. Dewantara, and M. S. Indriani, "Evaluasi Pelaksanaan Pembelajaran Bahasa Indonesia MPK Undiksha," Singaraja, 2015.

26. I. P. M. Dewantara, Int. J. Lang. Lit., 1(1), 19-29 (2017)

27. H. A. . Tilaar, Mengindonesia Etnisitas dan Identitas Bangsa Indonesia. Jakarta: Rineka Cipta, 2007.

28. B. Lestyarini, J. Pendidik. Karakter, 2(3), 340-354 (2012)

29. P. Le Ha, J. Kho, and B. Chng, J. Int. Comp. Educ., 2(2), 58-71 (2013)

30. J. Dupré, Curr. Issues Lang. Plan., 15(4), 393-408 (2014)

31. A. L. Robinson, Comp. Polit. Stud., 49(14), 1819-1854 (2016) 